C 113

\title{
デジタルホログラム粒子画像を用いた微小管内届折率計測
}

照沼 勇人○ (茨城高専専攻科)、池田 耕 (茨城高専機械システム工学科)

\section{Refractive index measurement by digital holographic Particle image for micro channel.}

Hayto Terunuma and Koh Ikeda.

\begin{abstract}
Crystallization inside micro channel is key technology to making new materials. In order to control the quality of crystal, solubility observation is required. Interferometry is technique to measure solubility using refractive index but it requires complex optical layout. In this paper new technique to measure refractive index inside micro channel using digital holographic technique are proposed. Calculated particle positions are shifted because of variation of refractive index. With this shift, the refractive index inside channel can be calculated. With simple experiment, feasibility of the technique are confirmed.
\end{abstract}

Keywords: Digital hologram, refractive index, micro channel.

\section{1.背景}

マイクロチャンネルを用いた科学技術は近年急速に成 長をしている1)。特にマイクロ管内を用いた結晶化さ せる技術が注目を浴びている ${ }^{2)}$ 。結晶の成長速度は溶 解度、温度、PH 等により変化するため、結晶の質を コントロールするためには各種のパラメータが溶液中 でどのように時間的に変動するかを知ることが重要で ある。一方で屈折率は溶解度と温度をパラメータとす る值である。そこで、溶液中の屈折率分布を実時間で 計测することにより、ある程度の制御を行うことが可 能になる。現在そのような用途には 2 光束干涉計が用 いられているが、顕微鏡下に 2 光束光学系を作成する ことはしばしば別の困難を与える。一方で近年開発 された、顕微鏡下での digital hologram ${ }^{3}$ )は 1 光束で十 分な制度で流体内の粒子の位置計測が行える。また、 粒子の再生位置は屈折率の影響より移動することがフ レネル回折式から導き出せる。本論では、digital hologram を用いた屈折率分布計測の手法の開発を行 った。

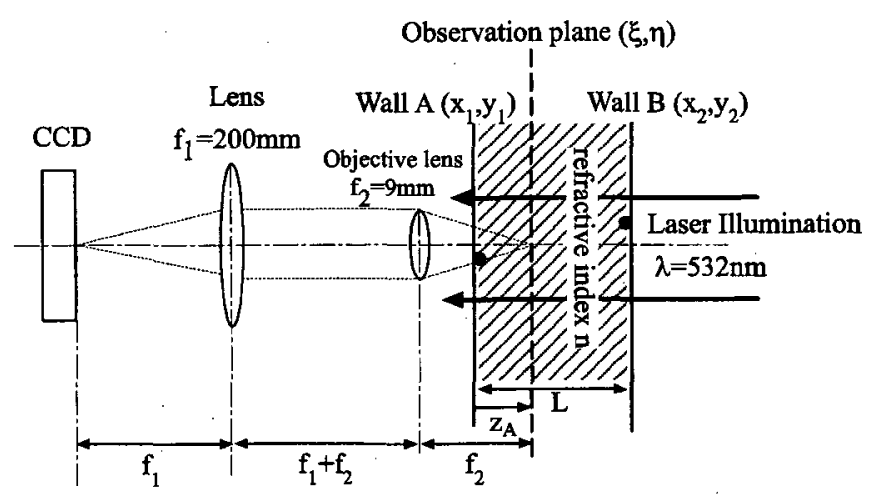

Fig. 1 Schematic view of microscopic Digital hologram.

2.手法.

Fig.1 に奥行きLのマイクロチャネル中の流体の屈折 率を計測するための、デジタルホログラムの概念図を 示す。CCDカメラは二つのレンズにより流路の中に縮 小されて、観察平面 $(\xi, \eta)$ で、粒子の回折を記録する。 壁 $\mathrm{A} 、$ 壁 $\mathrm{B}$ の座標を $\left(x_{1}, y_{1}\right),\left(x_{2}, y_{2}\right)$ であるとする。転送 された $\mathrm{CCD}$ の壁面 $\mathrm{A}$ からの距離を $\mathrm{zA}$ とする。今、流 路中に屈折率 $n_{1}$ の流体が流れていると仮定し、レーザ 一光の真空中の波数を $k=2 \pi / \lambda$ とする。壁 $\mathrm{A}, \mathrm{B}$ での 
れぞれの位置からのフレネル回折は以下の式で表され る。

$U_{A}(\xi, \eta)=\iint f \exp \left\{-i k\left[\frac{\left(x_{1}-\xi\right)^{2}+\left(y_{1}-\eta\right)^{2}}{2 z_{A} / n_{1}}\right]\right\} d x_{1} d y_{1}$

$U_{B}(\xi, \eta)=\iint g \exp \left\{-i k\left[\frac{\left(x_{2}-\xi\right)^{2}+\left(y_{2}-\eta\right)^{2}}{2\left(L-z_{A}\right) / n_{1}}\right]\right\} d x_{2} d y_{2}$

今流路内に屈折率 $n_{2}$ の流体を流す。すると、屈折率の 影響により、CCD カメラがレンズにより転送される位

置が変化し、 $z_{A}{ }^{\prime}=n_{2} z_{A} / n_{1}$ となる。この值を用いて 同様にフレネル回折を計算すると以下のようになる。

$U_{A}(\xi, \eta)=\iint f \exp \left\{-i k\left[\frac{\left(x_{1}-\xi\right)^{2}+\left(y_{1}-\eta\right)^{2}}{2 z_{A} / n_{1}}\right]\right\} d x_{1} d y_{1}$

$U_{B}(\xi, \eta)=\iint g \exp \left\{-i k\left[\frac{\left(x_{2}-\xi\right)^{2}+\left(y_{2}-\eta\right)^{2}}{2\left(L / n_{2}-z_{A} / n_{1}\right)}\right]\right\} d x_{2} d y_{2}$

式（1）と（3）は全く同じ形となり、（2）（4）を 比較すると、壁 B の位置の再生時に

$$
\Delta z=L\left(\frac{1}{n_{1}}-\frac{1}{n_{2}}\right)
$$

のずれが観測される。再生位置の差 $\Delta \mathrm{z}$ は移動量に関 係なく、管幅 $\mathrm{L}$ と屈折率 $n_{1} 、 n_{2}$ のみに依存して決ま るものということが分かる。つまり、管幅 L、屈折率 $n_{0}$ が既知な液体と屈折率の未知な液体を用いてそれぞれ 実験を行い、実験值 $\Delta \mathrm{z}$ を求めれば、式（5）より未 知の液体の屈折率 $n_{2}$ を求めることができる。この屈折 率により流体の濃度を知ることを可能にする。

\section{3.実験および結果}

Digital Hologram で撮影した壁面粒子の見かけの位 置を用いた屈折率計測の実現可能性を調查するため、 以下の実験を行った。光源としてレーザー(ND:YAG, $\lambda=532 \mathrm{~nm}$ )を用いた。レーザーは平行光にされ、流路 奥行き $110 \mu \mathrm{m}$ のマイクロチャンネルに照射する。マ イクロチャンネルを通過した光を対物レンズ $(\mathrm{f} 2=9 \mathrm{~mm})$ 、凸レンズ $(\mathrm{f} 1=200 \mathrm{~mm})$ を用いて拡大し C C Dカメラで撮影する。測定物体は、マイクロチャ ンネルの壁面に付着している粒子を用い、参照用の流 体として水（屈折率 $\mathrm{n}=1.33$ ) を用い、対象流体を $100 \%$ エタノール（屈折率 $\mathrm{n}=1.36 ）$ を用い、 $z_{A}=10 \mu \mathrm{m}$ とし ホログラムを撮影し、計算機により奥行き方向 $1 \mu \mathrm{m}$ 毎再生し、粒子の強度分布を計測した。Fig. 2 に撮影
壁面 $\mathrm{B}$ 上の粒子の強度を示す。

壁面 $\mathrm{B}$ 上の粒子は光強度の頂点が水の場合で $74 \mu \mathrm{m}$ 、 エタノールの場合で $72 \mu \mathrm{m}$ にあり、差は $2 \mu \mathrm{m}$ である。 一方、式(5)および、実験条件より計算されるずれは $1.82 \mu \mathrm{m}$ である。実験値と理論值は概ね一致しており、 本手法の妥当性を示している。計算ステップをさらに 細かくすることにより、より妥当な值が計算可能であ る。

\section{4. 結論}

微小流路中の屈折率分布を計測する手法を提案した。 また、水とエタノールを用いた実験により、その妥当 性を示すことができた。

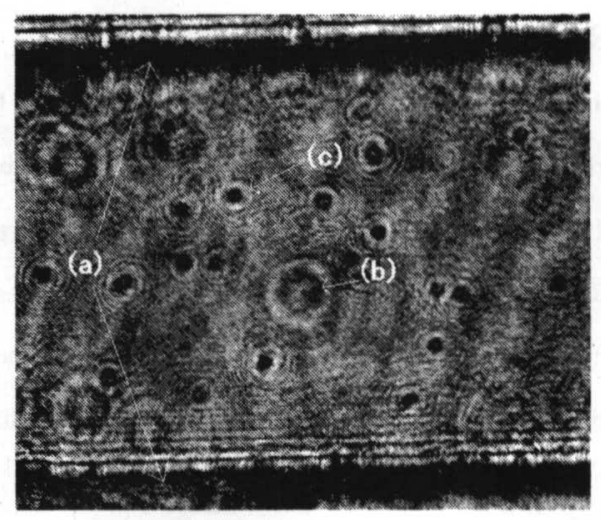

Fig.2 Hologram Image : (a) micro channel (b) particle on wall B (c) particle on wall A

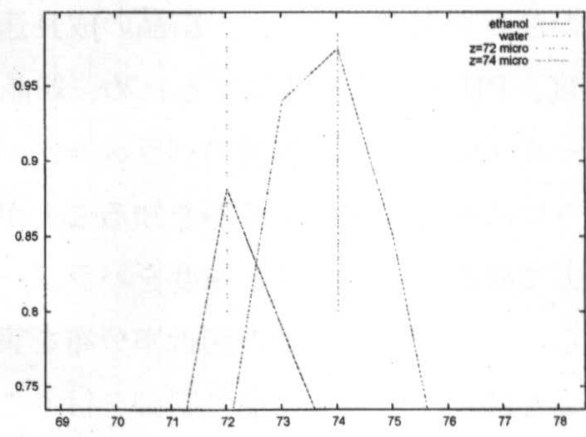

Fig.3 Calculated Particle Intensity on the wall B from digital holography

\section{参考文献}

1) Sugii. Y et.al. : Journal of Visualization, Vol.8,No.2(2005)117-124 2) Kyousuke Shinohara et.al. ,American Chemical Society,PAGE EST:3.3(2006)

3 ) K. Ikeda et.al. : Proc of joint International PIVNET II / ERCOFTAC Workshop pp 60 